\title{
Science and Passion in America
}

\author{
Rafael Sagredo Baeza \\ Instituto de Historia, Ponticia Universidad Católica de Chile, Santiago, Chile \\ e-mail: rsagredo@uc.cl
}

Received: 1 July 2012; Accepted: 2 September 2012; Published online: 8 January 2013

\begin{abstract}
In addition to increasing our knowledge and understanding of the naturalists who explored America at various times, particularly in the 18th and 19th centuries, we seek to discuss the personal, intimate, private, and sentimental nature of individuals who are usually described as well-bred, parsimonious, unfeeling, objective, rigorous, and methodical. For the same reason, perhaps, they are assumed to have stayed aloof from any form of sentimental or passionate relationships in the course of their excursions, despite the fact that the latter often lasted not for months but for years, and that in some instances were not conducted overland but involved prolonged voyages on the high seas.
\end{abstract}

KEYWORDS: history of science; American history; naturalists; passions; emotions

Citation / Cómo citar este artículo: Sagredo, Rafael (2012) "Science and Passion in America". Culture \& History Digital Journal 1(2): m103. doi: http://dx.doi.org/10.3989/chdj.2012.m103

RESUMEN: Ciencia y pasión en América.- Además de avanzar en el conocimiento y comprensión de los naturalistas que exploraron América en algún momento, particularmente en los siglos XVIII y XIX, nos interesa relevar la dimensión personal, íntima, privada, sentimental, de sujetos que corrientemente son presentados como hombres comedidos, parcos, fríos, objetivos, rigurosos y metódicos y, tal vez por eso, se supone, ajenos a cualquier tipo de relación sentimental o pasional durante sus excursiones. Esto, a pesar de que muchas de ellas se prolongaron no ya por meses, sino que por años y que algunas de ellas no fueron itinerarios terrestres, sino que esencialmente marítimos, con largas temporadas en alta mar.

PALABRAS CLAVE: historia de la ciencia; historia de América; naturalistas; pasiones; emociones

Copyright: (C) 2012 CSIC. This is an open-access article distributed under the terms of the Creative Commons AttributionNon Commercial (by-nc) Spain 3.0 License.

\section{PRESENTATION}

The subject of this article is eloquently set forth in the letter that Francisco José Caldas, a naturalist from Nueva Granada, wrote on 21st of April 1792, in deep anguish and despair, to his friend, botanist José Celestino Mutis. Referring to the arrival in Quito of Alexander von Humboldt and particularly to the behaviour of the latter in that city, he writes: "How different was the conduct of the lord baron in Santafé and Popayá from what he shows in Quito. The baron enters this Babylon, unfortunately makes friends with obscene dissolute young men who drag him to houses of ill repute, where a shameful passion seizes his heart, and blinds this young scientist to a point that is hardly believable" (Caldas, 1978: 169, 170).

Save the passion for knowledge, of which there are numerous and edifying examples in the course of 
History, study, the pursuit of knowledge, principles, and the causes of things, that some individuals undertake, are not usually associated to passion. On the contrary, it is commonly supposed that persons of high scientific talent are practically immune to emotion and that in them logical thought always triumphs over the subjective. It vanquishes the perturbation, the disorder of the soul caused by feelings of love that kindle a vivid, overwhelming inclination of one person for another. This uncommon association between science and passionate love is what we shall endeavour to show below, through the study of a few instances.

How did they reconcile the demands of their scientific purposes with their nature? How did they subdue their instincts, their vigour, their privations, and raptures? How was their conduct affected by sharing life for prolonged periods in a hostile natural environment, frequently short of funds, with no form of privacy available, not even for the calls of nature? How did they compensate for the distance between them and their loved ones, and the need for affection, caring, and understanding in the midst of cultural surroundings most of the time completely different from those to which they were accustomed?

We have no answer to such questions: however, our purpose is to raise them and pose them as a historic problem, because -we think- they were the cause of attitudes, conducts, and doings that concerned the purely scientific activities of the heroes of these fascinating histories. We shall see below how the study of nature was not the sole concern that drew their attention in the course of their campaigns in the field.

The rebuff suffered by Caldas upon Humboldt's decision to continue his travels in America in the company of Carlos de Montúfar -it is not for nothing that the scientist from New Granada refers to him as an "Adonis that does not hinder him in his travels as Caldas does"- was not only "a slight that this scientist will never succeed in curing" (Caldas to Mutis, 21 June 1802, in Caldas, 1978: 182), it also enables us to open a discussion of the raptures of love that overcame some of the naturalists who explored America. We shall glimpse some of their primary emotions and humanize them (figure 1).

As Caldas observed about Humboldt, "by mixing their weaknesses with the sublime functions of science" (Caldas to Mutis, 21 April 1802, in Caldas, 1978: 170), the conduct of certain scientists in America will enable us to observe fervours, passions, impetuosities, uncontrollable sexual drives that more than once caused anger and disputes, as well as the failure of their undertakings.

\section{ANDEAN PASSIONS}

The sentimental attachment suggested by José Caldas between Humboldt and Carlos Montúfar y Larrea, which would explain why this young man

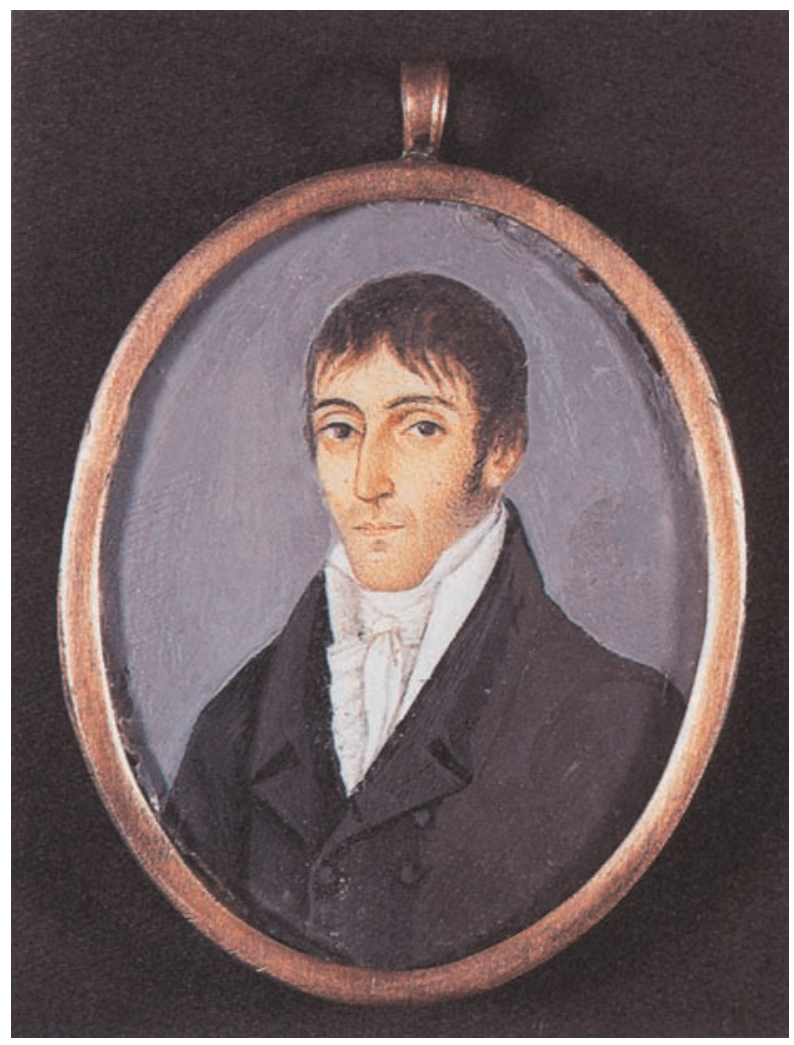

Figure 1. Francisco José de Caldas, anonymous portrait of the scientist from Nueva Granada, whose resentment at not being selected by Alexander von Humboldt for his American journey inspired correspondence where passion is eloquently expressed. Aquarel on Ivory. Casa Museo del 20 de Julio de 1820, Bogotá.

from Quito continued to travel in the company of the Prussian naturalist and Aimé Bonpland, including the voyage home in 1814, grieved Caldas deeply; as he writes to his correspondent: "I never imagined that he would deny me his company and not allow me to travel with him to Mexico and Ecuador, preferring instead an ignorant, unprincipled, and dissipated young man", as he described Montúfar (Caldas to Mutis, 6 April 1802, in Caldas, 1978: 166).

In the thousands of pages that Alexander von Humboldt wrote about his American travels, references to life with the young man from Quito are few and far between. Of course there are descriptions of activities undertaken jointly, in the company also of Bonpland and others, including climbing, botanizing, observing, and measuring. However, the fact is that indications of the form that their relationship took, the spaces of intimacy they shared, and other signs of association between two individuals who undoubtedly got on well together, are minimal and highly indirect. But they are there.

In Quito Humboldt and Bonpland, with Caldas, lived for almost a month at the Hacienda of Chillo, owned by Juan Pío Latúfar y Larrea, second Marquis of Selva Alegre and a distinguished member of the Audiencia, whom Humboldt describes as "zealous in 
the progress of science, a generous and enthusiastic patriot". There he met the sons of the Marquis, including Carlos, twenty-one years old, "a most amiable young officer, full of that ability to learn everything that characterizes true talent", and who, compared to his elder brother, "showed more energy than Xavier" (figure 2).

Humboldt's first impressions of Quito and the virtues of its population were highly positive. He writes in his diary that the city "is perhaps, of all the countries in America, the one with the greatest natural talents. The inhabitants show certain lightness, an ability to learn everything that singles them out in a favourable way. These qualities are to be admired particularly among the young people", he added (Humboldt, 2005: 114). ${ }^{1}$ Perhaps Humboldt's opinion was influenced by the fact that during his stay with the Montúfar family, while he drew the maps of the Orinoco and the River Negro, he taught Carlos to "survey, to draw (lay out) military positions" (Humboldt, 2005: 120). Carlos Montúfar, in turn, as one of his most important biographers reports, "was bewitched by the instruments and conversation of Humboldt" (Beck, 1971: 205).

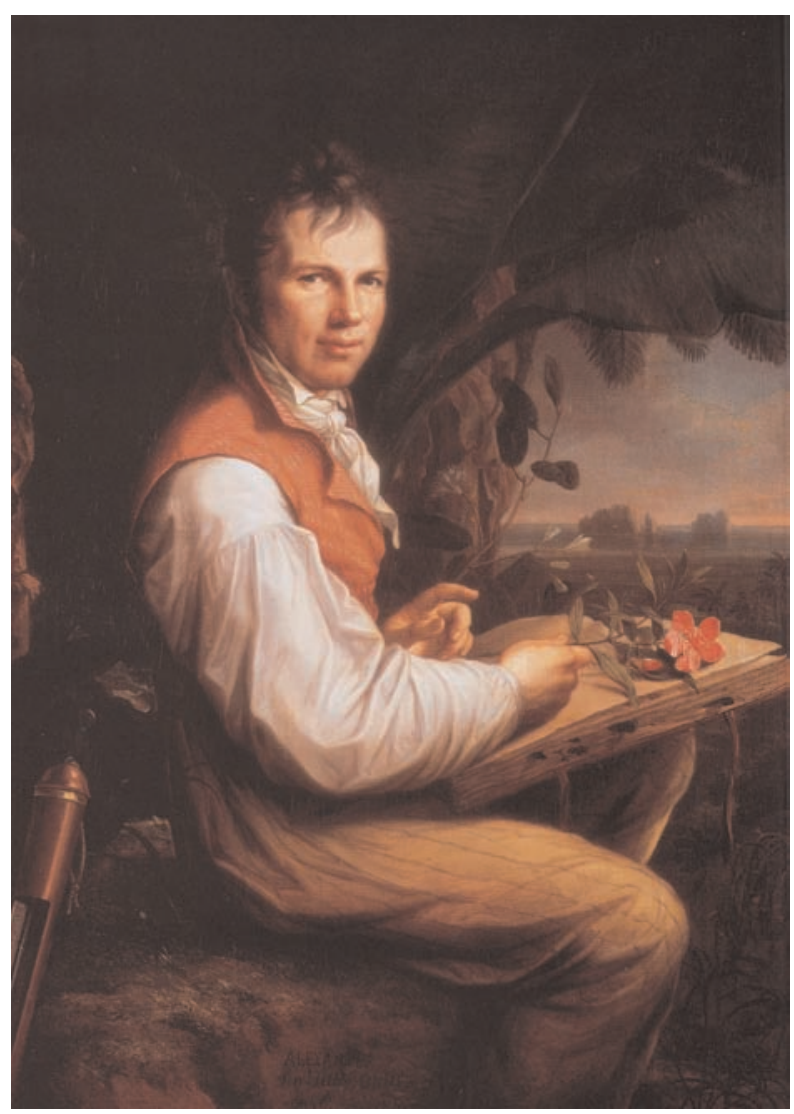

Figure 2. Alexander von Humboldt in America working on Botany. The oil painting by Friedrich Georg Weistsch emphasizes the vigor and sensuality of the naturalist surrounded by an idealized landscape. Oil on Canvas. Alte Nationalgalerie, Berlin.
With him and other companions Humboldt organized several expeditions, some to the volcanoes surrounding Quito. In each of his reports, Humboldt individualizes his companions, but Montúfar is the only one sometimes mentioned by name with the addition of a brief descriptive phrase. For instance, in his report on climbing the Pichincha, he mentions him, adding "our faithful friend on all our expeditions"; or on climbing the Cotopaxi, he is called "our permanent companion"; at another point he is referred to as "our friend" (Humboldt, 2005: 144, 149, 161). In his diary, Humboldt does not explain the addition of the quiteño to the expedition. He only describes setting out from Quito in the direction of Ambato on the 9th of June 1802: “Also señor Carlos Montúfar, second son of the marquis of Selva Alegre, whose family had welcomed us with unparalleled generosity, came with us as a member of the expedition" (Humboldt, 2005: 177).

At times his report enables us to visualize other forms of activities shared by Humboldt and Montúfar, and the enthusiasm that Nature aroused in him, in the company of the latter. In July 1802, on the road from Loja to San Felipe, they left the group at the "Friar's Falls" in the direction of Tablón. "I went there for a walk in the night with Carlos to botanize and contemplate the River Calvas from a certain height. We sat there for a long time, with our eyes fixed on the cordillera, and the immense deserts around it. It was a magnificent night; the Moon, Venus, Jupiter, and Saturn very close to one another," writes an inspired Humboldt.

Owing to the commotion of that "magnificent night", on their return they lost their way and wandered for 3 or 4 hours on the mountainside covered with vegetation, went into a dangerous forest, and skirted ravines, until they came to "the desired house", which, however, "was not ours". Humboldt continues his narrative stating "we were tired and resolved to spend the night in the open with no supper or bed". At that moment they heard "Bonpland shouting" and followed his voice until they found him. "Our blacks and he had been searching for us for the past hour. Finally, we came up to him and discovered, to our surprise, that though I had intended to set a course by the stars, our hut was situated in the directly opposite direction from where we supposed it to be" (Núñez and Petersen, 2002: 34).

This was not to be the only time in his exploration of the Andes that the naturalist would forget his talents as a scientist. Further on, after eighteen months spent "covering incessantly every nook and cranny in the interior of these mountains", filled with "impatience to feast our eyes again on the amplitude of the sea", which, Humboldt writes, "increased with the disappointments so many times felt" because of distance or fog; when, "overexcited by that desire", in mid Andes, "we climbed these mighty ridges". He continues, "while our guides promised us from hour to hour the fulfilment of our wishes", with the 
"impatience I felt to see the Pacific Ocean from the Andes Mountains", after having crossed countless ripples of the land, at the top of the Alto de Huancamarca, he adds: "then suddenly the vault of the sky cleared, the wind swept away the mist, and the deep blue appeared across the atmosphere of the sierra, between the sharp outlines of the higher clouds. Thus we beheld the South Sea for the first time, and we saw it so clearly, radiating an enormous mass of light on the coast and rising in its immensity to the horizon in the hazy distance" (Humboldt, 2003: 414-417). At the time, a moment of solemnity, before the view that had been so eagerly sought, "the joy that I felt and was shared to an equal degree by my companions, Bonpland and Carlos Montúfar, made us forget to observe the barometer", so that he failed in his duties as a zealous scientist. But then, he did meditate on the origin and satisfaction of desires, "linked in each one of us to the fleeting emotions of our youth", concluding that "the days when such desires are fulfilled stand out in our lives as unforgettable times, arousing sentiments in us whose intensity requires no rational explanation" (figure 3).

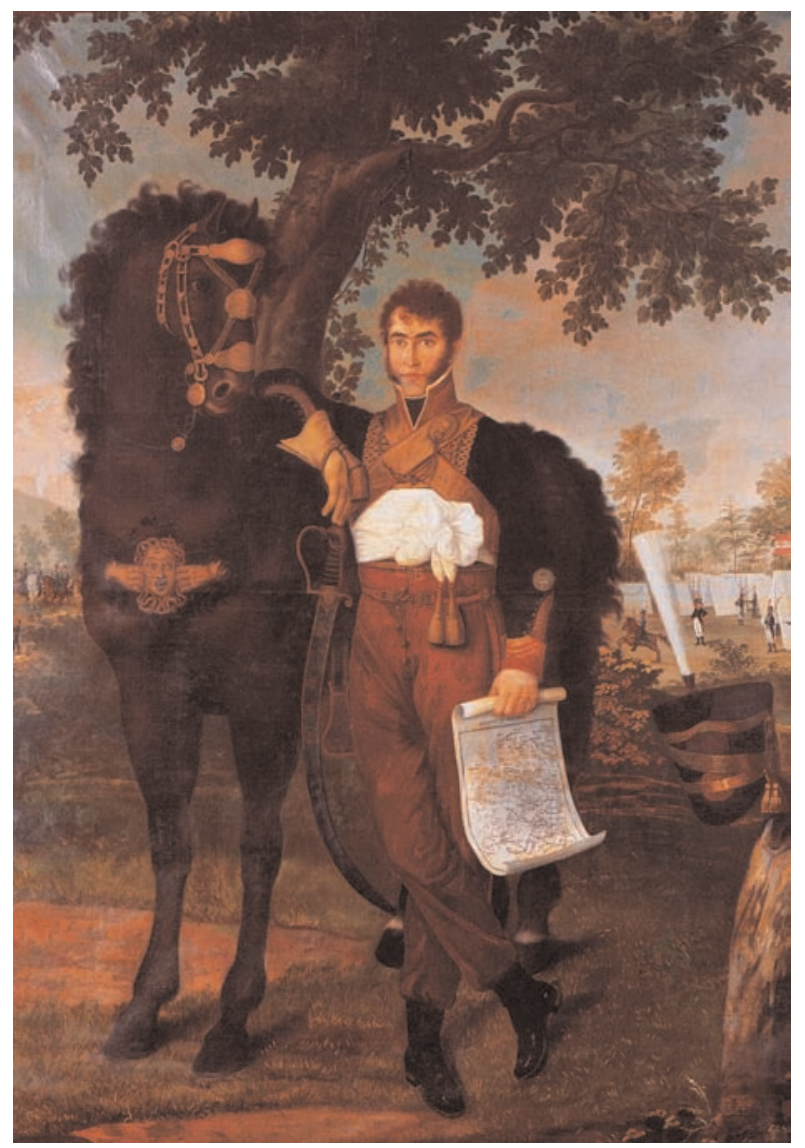

Figure 3. Carlos Montúfar y Larrea, anonymous portrait. The figure, posture, and attitude of the young patriot, as well as his character, attracted the naturalist so much that he added him to the other members of his American journey. Private collection.
His description of the moment is eloquent and explains his carelessness and his earlier disorientation. "What joy! For close on 18 months we have been in the interior of the continent. Seeing the sea is like gazing on an old friend, our heart opens, our imagination fills with a thousand ideas of communication, of bliss". After wandering for over 4500 kilometres, Humboldt writes in his diary, driven by overwhelming emotions, "What a sum of joys and sorrows! How small and narrow is the real world beside what man brings forth, burning in the depth of his feelings" (Núñez and Petersen, 2002: 72).

The close relationship between Carlos Montúfar and Humboldt did not arise from a sudden rapture, a passing whim of the latter. ${ }^{2}$ So at least is revealed by events in 1803, when the travellers were on their way to Mexico, in order, Humboldt tells, to enable the younger man to seek out an old friend, a woman named "Marica".

The home of the Marquis of Selva Alegre was also the residence of María Ontaneda Larraín. Known in the family as "Marica", a wealthy native of Quito, born in 1772, that certain scholars appear to associate in some way with Carlos Montúfar (Moreno Yáñez, 2005: 34-35). On the way to Acapulco, while stopping at Guayaquil, having heard about the eruption of $\mathrm{Mt}$ Cotopaxi, Humboldt decided to travel to Quito to observe it. As Bonpland remained in Guayaquil, "Carlos and I set out", the Prussian scientist remarks in his diary. However, having heard that there was a ship ready to sail to Mexico, he changed his plans. "On the instant I decided to give up the journey to the Cotopaxi and return. Charles (as he calls Carlos Montúfar) was full of rage and pain". "The reason," he asks himself then, "was he aware that Mariqua, the Queen, had travelled to Riobamba to meet him?" In fact, this incident ends with the following words, revealing his interest and the qualities he saw in the young man: "I had the greatest difficulty in dissuading him. He did not believe we would leave. Finally, he gave in, because he is very gentle and a very good boy" (Humboldt, 2005: 266).

While the American excursion was in full sway, José Caldas, seeking consolation, explains Humboldt's option because the "air of Quito is poisonous" and it is a place where "one breathes only pleasures", and where "the precipices, the perils of virtue are manifold, and one might think that the temple of Venus has moved from Cyprus to this city" (Humboldt, 1989: 153).

This view should not be understood solely as an attempt to justify the inexplicable or the result of animosity. Alexander von Humboldt himself, in a letter to his brother Wilhelm dated in Lima, on the 25 th of November 1802, several months after his stay in Quito, wrote: "The inhabitants of Quito are lighthearted, high-spirited, and kindly. Their city breathes only voluptuousness and luxury, and nowhere is there a more decided and general bent for pleasure" (Humboldt, 1989: 82). ${ }^{3}$ 


\section{FOOLISHNESS AND INDISCRETION}

The explanation that Caldas gives for the behaviour of the Prussian scientist may perhaps also serve to explain another incident caused by passion, which ended, on that occasion, by seriously jeopardizing one of the most renowned scientific undertakings of the 18th century. One of the protagonists involved is Louis Godin, whose "follies in Peru" (in the Viceroyalty of Peru, but actually in Quito) were as well known as his reputation as a scientist (Badinter, 2007: 50). He took part in the expedition that the Paris Academy of Science decided to send to Peru; an expedition to Lapland was also organized under Maupertuis, both with the object of measuring one degree of a meridian in order to resolve once and for all the polemic on the shape of the Earth. This astronomer was one of the leaders of that expedition together with the mathematician and astronomer Pierre Bouguet. Charles Marie de la Condamine and other renowned scientists were also part of the group. ${ }^{4}$

The adventures of the French in America, of Godin and others, particularly those foreign to science though not to nature, were widely discussed in Paris, for the correspondence they sent to Europe was rapidly disseminated by its addressees among the members of the Academy and the court. ${ }^{5}$ It is thus possible to hear of the disorder of the expedition, its material and financial straits, as well as the personal animosities among its members, owing to which some, such as La Condamine and Bouget, were not on speaking terms with Godin.

Even prior to setting out, the expedition destined to resolve the debate between Newtonians and Cartesians on whether the Earth was shaped like a spheroid flattened at the poles or, instead, at the Equator, appeared difficult because of the non-scientific challenges that the environment, nature, and a sparsely populated area, poor communications, a hostile population, and corrupt authorities were to impose on the expeditionaries. Moreover, the organizers of the undertaking were aware that a leader was needed endowed with outstanding qualities, "a man whose activity would grow with obstacles, who would also be prepared to give up his fortune, his health, and even his life for the success of the undertaking; someone who, drawing strength from the natural vigor of his soul, would possess all the forms of courage" (from Éloge de La Condamine by Jean Antoine Condorcet, see Badinter, 2007: 66), and that was not, precisely, Louis Godin.

The forecasts of the challenges that the scientists were to find in Quito were not mistaken; proof of this is that some of the expeditionaries remained in America from nine to twenty-seven years, suffering a variety of mishaps including two deaths from sickness and murder; two prosecutions for smuggling; one prosecution for contempt of authority; one war between Spain and Great Britain that cut off their communication with Europe; also a civil uprising that exposed them to the violence of the opposing factions, and other calamities in addition to financial penury, the trials arising from a hostile nature, and the disagreements among the protagonists of the scientific undertaking. ${ }^{6}$

Well known as a womanizer, even before arriving in Quito, while still in Martinique his companions began to complain of Godin's behaviour. For example, Jean Séniergue, surgeon of the expedition, wrote on the 4th of July 1735 to botanist Antoine de Jussieu that "most of us are on bad terms with him and all say that unless he changes his tactics it will prove impossible to live with him". 7 The attitude of the mathematician failed to improve in the Andes, in fact it became worse for he neglected his duties, as physician-naturalist Joseph de Jussieu reports to his brother Antoine: "monsieur Godin, our chief and treasurer, has for some time neglected astronomy in order to deal with a more urgent matter". The cause of the situation, according to the scientist, was passion. "Love is what occupies him to the full", and he writes further that "I trust his wife will nor hear of the unfaithfulness of her Adonis", adding that "it is a cruel thing that the money required for the purposes of the company be spent on the vanity, luxury, and whims of a man who, in his position, ought to be a model of good sense, prudence, zeal, and thrift". An instance of the misconduct reigning in the commission was that "the draughtsman is busy on a portrait of the young lady named Guzan and of the mulatto manager of a brothel whose name is Bastienne", also that "much money is spent on satisfying the appetite of the young lady", and as the courtship is generous with dresses, snuffboxes, etc., we must witness it and suffer from it", he adds. ${ }^{8}$

Accused of being a veritable tyrant vis-à-vis his companions, Louis Godin was censured for having unscrupulously spent on his personal pleasures the funds granted. As a result, while he enjoyed a life of ease and showered gifts and jewels on his local mistress, his colleagues barely survived, even when their precarious situation was no impediment for some of them, like the physician Jean Séniergue, similarly to give way to passion.

Although the unfortunate end of the medical man is the subject of controversy, among other reasons, because the events in which he was involved and which led to his death were not exactly edifying for the "official history" of the scientific expedition in which he took part, the truth is that he was proved to be a philanderer. The favours of a creole woman named Manuela Quesada captivating him aroused the jealousy of another man who was involved with her, and -just as important- upset the people of Cuenca, who objected to his behaviour and accused the French of being libertines and agnostics, if not atheists. This event, in the midst of a conservative society dominated by the Church and a highly traditional elite, it is 
argued, also influenced the rebellion that finally cost Séniergue his life in 1739. Among other reasons, because they represented values that countered Spanish customs, in a tense environment, inimical to reforms and where the arrival of the French mission was viewed with annoyance and misgivings (Hernández Asencio, 2008: 170).

On the fateful day for him, anxious to show himself with his paramour at a bullfight, on the feast day of Our Lady of the Snows, Séniergue appeared with her showing conceit as well as scorn for the local society, together with his well-known mockery of a certain local priest. All of this in the midst of a crowd estimated at four thousand persons. Matters came to a head when Diego León y Román, one of the leading citizens and also involved with Manuela, demanded that the French group pacify the physician, who had lost his temper. This led to words with Séniergue. From words to deeds was the next step in the quarrel, which became a fight and spread little by little to involve everyone present, until the Frenchman was wounded and fell. Four days later he was dead. ${ }^{9}$

According to La Condamine, the relationship between Jean Séniergue and Manuela Quesada, who cohabited with the consent of her family, was just an excuse made up by the aggressors, encouraged by the Vicar of the city and Nicolás de Neira. In fact, the actual reason for the events was animadversion for the scientists, all of whom seriously risked being attacked by the crowd. ${ }^{10}$ Accordingly, the accusation of concubinage against Séniergue, which undoubtedly originated a personal conflict, was only a pretext to express the tensions built up within a traditional society, under severe economic stress, that found in the Frenchmen a way to relieve the existing troubles (Hernández Asencio, 2008: 176). Nonetheless, for the historiography of Ecuador, "many among the people had already petitioned that the excesses of Séniergues be repressed". 11

Although the letter from La Condamine to señora *** is intended to vindicate his countryman, overlooking what in Cuenca was considered libertine behaviour and open scorn of local customs and feelings, the fact is that even in his words there is evidence of what he terms "indiscretion of the unfortunate Séniergues".

The letter records his attraction to Manuela, "a pretty young girl", whom he met when he was called to care for her sick father; his intervention in the affairs of Manuela and Diego de León because of a breach of promise of marriage; the "violent actions of Séniergues" towards León on some occasion, described by La Condamine as "his greatest fault and the origin of his misfortune;" the prosecution for public concubinage with Manuela, moved by the Vicar General of the Bishop of Quito; how Séniergues paraded in public with Manuela during the bullfights; the quarrel with his rival, and the insults and threats that the surgeon uttered against him; and, lastly, the quick and nervous events that led to the death of Séniergues, who, it seems, had caused them because as La Condamine points out- "he could not control himself".

After a few years of fruitful work in spite of quarrels and privations, particularly from 1738 and the beginning of 1740 , when the measurements obtained had served to complete almost all the tasks entrusted, the geodesic expedition headed by Godin began to disintegrate (Hernández Asencio, 2008: 105). In addition, the commission sent to Lapland had returned to Paris and the data collected by Maupertuis showed that Newton was correct and the Earth was shaped like a sphere flattened at the poles. At that point the undertaking collapsed and each of the members began to act for himself and attend to his own affairs, while the inability of Godin to lead his men and give the mission a sense of shared achievement was obvious (Hernández Asencio, 2008: 117-128).

Aware that he would not be welcome in Paris, Godin settled in Lima, where he lived until 1751 in charge of the chair in Mathematics at the Universidad de San Marcos. ${ }^{12}$ His decision, however, led to his exclusion from the Academy of Science of Paris in 1745 , for having chosen to reside in Peru. ${ }^{13}$ The foregoing shows that, as Elizabeth Badinter has so aptly suggested, "intellectual passions" do exist, and in the struggle for power, fame, and celebrity among scientists, no one spares reasons. Badinter interprets the expulsion of Godin in the context of power struggles among scientists.

The degrading of Godin was not solely due to his poor leadership of the commission entrusted to him. It must be pointed out that at the time, the first half of the 18th century, although scientists fled from neither women nor the world, they did pursue certain asceticism and marriage was frowned on; it was held to be unforgivably ridiculous. It was understood that given the modest incomes of scientists, the cares of matrimony and raising a family were a veritable obstacle in the way of a vocation. However, over and above marriage, what was held to be totally incompatible with high-level intellectual work was sexual intercourse. As has been said, "asceticism defined the way of life of most scientists" of that time (Badinter, 2007: 34-36).

Louis Godin finally managed to return to Europe. Moved by homesickness for his native land or the memories of his wife and children abandoned in 1735 , he arrived in Paris in 1751 . He then returned to his marriage and reorganized his married life, but he was also busy recovering his seat in the Academy, to which end his appointment as Director of the Midshipmen School in Cadiz made a notable contribution.

Accompanied by his wife and children, and with permission from the king of France, he took possession of this post. Then, with his family, he had re-established his position and would shortly be readmitted to the Academy of Science, which took 
place in 1756. His wanderings and foolish indiscretions in America were left far behind.

\section{FORBIDDEN PASSIONS IN CHILOÉ}

In the history of the geographic survey of the coasts of America undertaken by Spain in the 18th century, José de Moraleda y Montero, an unknown pilot, earned much praise as hydrographer. Though practically forgotten by historiography, the greatest naval officer in the service of the Royal Armada in his time, Alejandro Malaspina, appreciated him. In a letter addressed to the Minister for the Indies, Antonio Valdés, in 1780, the Italian-born captain wrote: "Your Excellency, before leaving Spain, the reports from a large number of officers in the Armada, together with those I had acquired in Lima when I came to the Peruvian coast in the frigate Astrea, had given me a highly praiseworthy notion of the talent, performance, and honesty of the First Pilot graduate Ensign José de Moraleda. However, after comparing his works with ours, dealing with Moraleda himself, and, lately, having him with me for two months for the making of several charts and drawings, I cannot but advise Y.E. that, truly, this individual has acquired singular merit, devoting himself with no thought of personal gain to increasing his knowledge, and at once addressing it to the public weal, in a country where he could not rely on the aid of many nor feel free from the temptations to idleness from the many courtesies that the land extends to the newcomer. The practice he has acquired on these seas, furthermore, would make him most useful in the royal service and this together with these objects will justify the liberty I am now taking in recommending him particularly to the protection of Y.E". 14

The opinion of Captain Malaspina was supported by Moraleda's career in the South Seas, but above all by his hydrographic commissions in the South Pacific, in the Chiloe Archipelago off the coast of Chile, between 1786 and $1790 .^{15}$

The recommendation from Malaspina contains all the elements for gauging the importance of Moraleda. There is his participation in the exploration and reconnaissance of the Pacific undertaken by Spain in response to the growing presence of English and French vessels on an ocean that had practically been a Spanish lake until the beginning of the 18th century; his career on the South Sea since he arrived in Callao in April 1773 and began to sail along the entire South American coast; also his exploration and study of island possessions scattered between America and Oceania; his practical knowledge and experience embodied in the cartography of Chiloé drawn up in the course of his years-long campaigns about the archipelago; but also the professional and human qualities that had led him to serve the monarchy with no personal ambitions and in an environment more favourable to relaxation than toil. ${ }^{16}$
In the life of Moraleda, however, there is a littleknown side that merits attention if we are to understand the professional work of this distinguished Spanish navy officer. Also to realize how, even among the most dedicated explorers and wise scientists, passions, sexual inclinations, break out to their full proportions, causing conflicts and -obviously- affecting their work and responsibilities. In the present case, the so-called "philandering" of the Spanish mariner in Chiloé, where it seems he did not leave a pleasant memory (Vásquez de Acuña García del Postigo, 2004: 989).

Though information on José de Moraleda is very scarce, in general, the available testimonies point to him as a seaman of "good conduct, competence, and accredited sufficiency in Mathematics, piloting, and manoeuvre, with outstanding capability in drawing"; in the words of some of his superior officers, "a complete officer on whom the king can count", owing to his merits and capability. ${ }^{17}$ The scholars who know him describe him as a man of "robust or good health", good judgment, and technical knowledge, "one of the best pilots of his time" (O'Donnell y Duque de la Estrada, 1990: 73). To the extent that in 1780 his name was put up to fill the first-pilot vacancy, without having to pass an examination owing to his performance and conduct (O'Donnell y Duque de la Estrada, 1990: 74); and that in 1783 his application for officer rank as first pilot ensign, was granted and he could fulfil his aspiration to be a war officer.

A few years later, in 1786, Teodoro de Croix, Viceroy of Peru, appointed him to Chiloé to assist Francisco Hurtado, the new governor of the island, in the task of making a large general drawing of the main island and adjacent islands, among other duties that would keep him in the southern end of America at least until 1790. The commission marked the beginning of a new life for Moraleda, but also of his difficulties with Governor Hurtado, who resented what he took to be non-compliance of the Pilot arising from conduct unbecoming in the course of his stay in Chiloé.

As established in the historiography, Moraleda and Hurtado clashed from the start, among other things owing to the authoritarian nature of the governor, but also because of the zeal that each showed in defending their prerogatives: one as political head, the other as officer of the navy, in relation to the commission with which they had been entrusted (O'Donnell y Duque de la Estrada, 1990). Not to refer just yet to events in the love life of the naval officer in Chiloe that undoubtedly conditioned his behaviour and the judgment of the governor.

The quarrels, in the form of controversy over practically any matter associated to the hydrographic commission, reached the point where the governor decided to collect proof to open a criminal suit against Moraleda. Among other reasons, because Moraleda in turn had developed a patient campaign to hurt the reputation of Hurtado, not only among the people he governed but also among his superiors, particularly 
Viceroy de la Croix, to whom he wrote in all confidence.

What interests us here is that Francisco Hurtado, in the successive papers he wrote and sent off on this subject, not only described the various failings and faults of Moraleda in his work: in addition, he described him as a man of immoral behaviour "perhaps the most audacious and perverse we have seen", he wrote to the King. ${ }^{18}$ While he told Antonio Porlier in May 1789 about the "daring and voracity of the pilot in the wicked and atrocious deeds whereof I have proof", including that taking advantage of the "simplicity" of the islanders "he has ravished a number of girls, both Spanish and Indian". 19

The accusation referred not only to the years that both had spent together in Chiloé; Francisco Hurtado contended that earlier, in 1786, Moraleda had already spent time on the main island with the fleet commanded by captain Antonio Vacaro, leaving behind bitter memories of his visit. "The depravity and endless crimes, the most atrocious of this fellow," Francisco Hurtado writes, "whom you have seen before when the fleet came to that poor province, a miserable little pilot calling from house to house selling ribbons and baubles, and sitting on the floor, like doña Bernarda Garay, an inhabitant of Chiloé, one of whose daughters he raped, in spite of her care". ${ }^{20}$

For Hurtado, proof of the dissolute conduct of Moraleda is the fact that the hydrographer refused to transfer to Lima once he had completed his commission, arguing that he had not finished making a clean copy of the drawings he had sketched. ${ }^{21}$ According to the statement by the former governor, who was at the time in Lima, removed from his post and held owing to the suit against him over his performance in Chiloé, "I do not know for what reason such stay of José Moraleda in that destination should be legitimate when working on the drawings, in the event of having to make another set, which is not needed (because for that reason I had him make the number of copies aforesaid) in this city [Lima] he might have made them more easily than there [Chiloé], where the poor light because the days are short and dark and the inclement weather make the work more difficult". As Hurtado's argument is reasonable and he knows it, he concludes: "Therefore, I infer that he has other reasons for staying".22

The accusations of Francisco Hurtado referring to the licentiousness of Moraleda or his sexual abuse of minor girls also reached his wife. Speaking of her life in Lima, where she lived with the pilot, she tells that his first wife had been the "sister of an actress and daughter of another", who led a scandalous life and had adulterous love affairs, among others with the French major-domo of Viceroy Teodoro de Croix. ${ }^{23}$ And it is precisely to this affair of the pilot's wife that Hurtado attributed the familiarity and friendship with which the Viceroy treated Moraleda.
Hurtado never formally submitted the serious charges against José Moraleda, even though he contended "they ought to be pursued because they are deeds that concern the weal of the State and the consciences of those in command, who know it and fail to remedy it" (O'Donnell y Duque de la Estrada, 1990: 101). From the prosecution, which brought humiliations and other hardships, Francisco Hurtado emerged unharmed for the cause against him was termed "illegal, inordinate, and slanderous" (O’Donnell y Duque de la Estrada, 1990: 89).

In any event, the extension of Moraleda's sojourn in Chiloé -and he must have had good reason as the weather there is inclement for the greater part of the year- was a great benefit for the empire and today for historiography, owing to the detailed knowledge of the archipelago that the pilot came to possess. Proof of this are the charts he drew, the routes he described, and the texts he wrote, among them the one titled Acaecimientos de alguna nota ocurridos desde el 17 de julio de 1788 en adelante (Events of some importance from the 17th of July 1788 onwards) and especially his Breve Descripción de la provincia de Chiloé, su población, carácter de sus habitantes, producciones y comercio (Brief description of the province of Chiloé, its population, character of its inhabitants, productions, and trade), where he shows a profound knowledge not only of local productions, number of inhabitants, industries, forces, etc., but above all of the character and ways of life of the dwellers on the island.

His absence, however, was not for long, as he returned between 1792 and 1796 to explore the coasts and islands south of Chiloé to Aysén. Then, and as in the course of his commission, every winter, his place of residence was San Carlos de Chiloé. ${ }^{24}$

\section{PASSION AND TRAGEDY IN THE TROPICS}

The Langsdorff Expedition is a scientific enterprise that from its characteristics is highly representative of the way in which science was being practiced since the time of the Enlightenment, but also of the fateful destiny that unleashed passions can arouse.

Headed by Georg Heinrich von Langsdorff, a naturalist of Prussian origin, under the protection of the Czar of all the Russias, the undertaking brought together a group of specialists including botanists such as Ludwig Riedel, zoologist Edouard Ménétriés, astronomer and geographer Nester Gavrilovitch Rubstoy, and artists Juan Mauricio Rugendas, Aimé-Andrien Taunay, and Hercule Florence, from the present Russia, Germany, and France, in addition to the Brazilians and Portuguese who joined it at some later point. That is, a multidisciplinary international undertaking, where the interests connected to the need to extend knowledge and take advantage of American natural wealth perhaps diluted the nationalities of its members, though not their personalities and tempers. 
Against what might be believed from the conditions of the participants, who were scientists trained for "objective" application of their particular method and for facing the challenges arising from exploration of unknown territories and threatening environments, from the start the undertaking was haunted by the subjectivity, the impressions, passions, and discomfort of the individuals who made it up, all of which contributed to its tragic fate.

Under the patronage of the Russian Academy of Sciences, the ambitious Project was originally intended to explore the interior of Brazil, study natural conditions, perform astronomical and geographic observations, document the experiences of the commission, and represent what was observed in the course of the journey through the Amazon region, which explains the presence of the artists. All proper objectives of a scientific undertaking, which on this occasion, however, failed to materialize.

The expedition that entered Brazilian territory in 1822 produced a multitude of texts and documents that help us to follow the day-to-day activities of the European scientific expedition on American soil. ${ }^{25}$ The existing sources enable us to reconstruct the origins of the journey in tsarist Russia, at the suggestion of Langsdorff, the organization and formalities required for a commission of this kind, the events during the journey, the life shared by its more than forty members, and the actual failure of the project.

In its conception, objectives, instruments, participants, and many other items, the Langsdorff Expedition shows the features pertaining to enlightened science, including relationship with the authorities of the country that will welcome the scientific undertaking. Such closeness with what was supposed to be the proper attitude for an enterprise of this nature, the rigid European model repeatedly and successfully applied throughout the 18th century would also lead to its ruin. No consideration was given to the particular, difficult, and challenging natural reality of the Amazonian tropics, nor to the new political status of the former American colonies, now independent states, where institutions and therefore sponsorships, supports, and resources failed to work, if they had ever done so, as the travellers expected. These were conditions that not only hindered the progress of the group of naturalists and artists, they simply made it impossible.

Among other reasons, because as the expeditionaries went deeper into the Amazonian jungle, they went farther from the world they knew, from its fundamental references, its habits, the cultural and natural reality that was theirs. Such things as lack of privacy and space, to name only one example from the daily life of the travellers, created insuperable tensions that began to undermine their mutual relations, and they found themselves in the midst of an unrelenting tension that ended by affecting their life together and rendered it impossible to complete the mission.

Lack of provisions and resources in the midst of hardships of all kinds, illnesses sufferings that caused despair and even the death of more then one explorer, were trials that befell the expedition. It was not that their sponsor failed in organizing the journey, it was that owing to its origin as well as the characteristics of its members, as we now know, it was doomed. Not to mention the obstacles arising from a tropical nature that the Europeans finally could not overcome as they lacked appropriate support networks.

First of all, there was the position of Langsdorff himself, who was acting as Russian consul in Rio de Janeiro since 1813; he had become a landowner and as a result could not neglect his own interests for too long. This actually happened during the trip, which he abandoned in order to attend to his business and affairs. His personality, clearly unsuitable for personal relationships, caused him to be constantly in conflict, first with the painter Rugendas, later with other members of his team, particularly Hercule Florence and Aimé-Andrien Taunay. Of his decisions, however, that of having his young wife accompany him was perhaps the most unfortunate for the operation of the enlightened scientific commission.

The presence of Wilhelmine, an unheard-of situation in the scientific undertakings of the time, altered the interior harmony of the group, as manifest in the letters of some of its members, who mince no words to show the passion they felt for her, to the natural annoyance of Langsdorff and with devastating effect on the group of expeditionaries.

The jealousy, reservations, and professional difficulties between Langsdorff and his subordinates, particularly Taunay and Rugendas, also made themselves felt from the beginning of the journey. First because of what the baron expected from his painters: a faithful record of what they had seen; later, over personal squabbles fed by a hopelessly disturbed way of life. ${ }^{26}$

The baron, however, was not only continuously at loggerheads with his associates, inter alia, owing to his pursuit of fame, originality, and glory. The documents point to his annoyance with the geographic environment and cultural conditions through which his journey took him. On the verge of losing his mind, he wrote: "I can do no more". Eloquent testimony of the condition of the mission he led.

The avatars of the expedition headed by an authoritarian leader incapable of communicating with his subordinates -who are not exempt from responsibility in this failed undertaking- include divisions, suspensions, desertions, sorrows, sacrifices, and deaths. For some, "a veritable epic. But an epic of sorrow, of discouragement, of abandonment, of daily struggle against hostile elements. Crowned by an unparalleled catastrophe". 
The first stage of the expedition, in Minas Gerais, was followed by the great journey to Sao Paulo and from there to the west central region of Brazil, over the ancient monçoeira route to Amazonia, where the expedition broke up entirely. Ménétriés and Rugendas left the expedition after the first stage, but Langsdorff's young wife, Wilhelmina, had joined the expedition in 1825 .

Little more that 20 years old, Wilhelmine was the second wife of the baron, with whom she already had three children. Though there is no explanation for her joining the expedition, it is on record that her presence unleashed the passions of some of the members of a caravan already tense from the temper of their leader, a harsh nature, differing notions of the duties of each member, and the desertion of some of the original participants.

The first to succumb to the young woman was the artist Hercule Florence, who fell in love with her badly enough to declare his love in writing, in letters that she showed to Baron Langsdorff, her husband. As Taunay wrote to his friend Francisco Alvares Machado e Vasconcelos, "the cruel woman laughed at his torment and showed the letter to the old man". Naturally, an already irritated Langsdorff did not remain indifferent; he reprimanded his subordinate and ordered him to "leave Wilhelmine alone, she is my wife". According to Taunay, "poor Florence was sad" and, apparently, also thought of leaving the expedition. This last determination he never carried out, although from then on he had to suffer the ill will of the baron, who, as he wrote on the 29th of November 1826, complained of his conduct with words like "Florence, as usual, is inappropriate and does nothing".

Until that time, Wilhelmine is frequently and lovingly mentioned in the diary of her husband as "my dear wife" or, more affectionately, "my dear Minnchen" or simply as "Minnchen", a German diminutive showing trust and appreciation. As the exhausting river route went on, however, and the events took place that associated her with artists of the commission, such mentions begin to dwindle until they practically disappear, signaling the ill feelings of the couple and that the baron changed his treatment of her.

Taunay, impartial observer of events, writes to Álvarez Machado without appearing to be involved with Wilhelmine. He goes to the extreme of describing a scene in which she takes part, and which, undoubtedly and as he says, banishes any possibility of falling in love, while it shows up the scant privacy available to the expeditionaries.

On the 26th of September, in the same note where he discusses Florence's love, he tells that the woman was taken ill, "for which I blamed the large number of fish that she eats. Baths, purgatives, etc. Ah, my friend! A question of shitting in front of everyone, and as for women, it is a great antidote against love". ${ }^{27}$ The emetic had no effect and the situation worsened when Taunay became enamoured of Wilhelmine. The young painter, overcome by his liaison and the events to which it gave rise, confided to his friend Álvarez Machado his feelings for her.

In a letter dated September 30th he tells that he continues to belong to the Russian Scientific Commission only thanks to Ludwig Riedel, a botanist, "who in difficult circumstances behaved toward me like an affectionate and tender friend". In a funereal and melancholy tone he tells that "he was the one who supported my stumbling steps on the edge of a precipice so much more perilous in that I myself, aware of its horrifying depth, sought to plunge, possessed by a spirit of vertigo that only his friendly voice caused to yield". The reason: "Wilhelmine is no longer with us and this step I owe to Riedel, who struck at the root of the evil and broke the spell"'. And concluded, "I made great mistakes that I shall regret all my life," seeking justification, "but of what is passion not capable".

Such fervor for Wilhelmine naturally worsened an already bitter association with Langsdorff owing to the different notions that each had of the artist's work. Thus, what had been "professional" differences now became personal and led Taunay to think of giving up the journey and Langsdorff to allow him to leave. He even wrote a letter of resignation where, obviously, he refers to Wilhelmine as one of the causes of antagonism between him and the naturalist. ${ }^{28}$

Langsdorff never mentions the passion that arose between his wife and Taunay, and was not prepared to let the artist go so as not to do even more damage to his undertaking, and the impasse was resolved, at least for the time being, by dividing the expedition in two groups. On one side the Baron with Rubzoff and Florence; on the other, Taunay and Riedel. And Wilhelmine? Quite simply, it was decided to exclude her and she returned to Rio de Janeiro.

Irreparably fractured, "as a result of the events that took place on the way, I was for long on bad terms with Langsdorff," Taunay writes, having remained with the undertaking on condition that it be divided into two groups; thus, by separating from the German Baron, "freeing myself from his importunities and allowing absence to cool down a certain hard feeling that, in spite of all promises, cannot but remain between myself and Langsdorff', ${ }^{29}$

Taunay was devastated after it was all over. Proof of this is found in a letter to relatives and friends in which he describes the palace in Vila Bela that was formerly the government palace until the government moved to Cuiabá; he tells of empty silent halls, "where everything reproduces the image of death". All in the midst of a feeling, he writes, that is "absolutely singular and poetic". and inspires him to exclaim "How many things have I to tell you!" His farewell evokes a deep sorrow: "May you enjoy the happiness that my heart desires and do not forget 
that I am unhappy. My character is melancholy though I show the outer signs of gladness".30

Broken up, the scientific-artistic venture came to a woeful end for the men in conflict. While Georg Langsdorff went mad on the River Juruena in May 1828, Aimé Andrien Taunay was drowned in the River Guaporé when diving recklessly into the water. His friend and fellow traveller, Ludwig Riedel, who witnessed the event, wrote: "Nothing could distract him from his fatal resolution. He dived into the river to swim: he reached the middle of the river, became weak, sank, surfaced with a horrible cry, lifted one hand... and our Taunay was the victim of his own recklessness" (Costa and Diener, 2013).

The original expectations, as well as the tragic fate of the Langsdorff Expedition as the sources describe it, lay open the excesses of an undertaking that failed to consider the natural and social circumstances that would confront it; the physical and moral imbalance of its leader; the different social ranks of its members; the inordinate self-esteem of some of the members; the ups and downs that personal relations underwent within the group; the quarrels, the mutual, crossed, constant antipathies; the romantic spirit of some, the rationality of others; the frivolity or the lewd habits attributed to several; the loving and unloving of Wilhelmine with Taunay and her husband; the strife, jealousies, and impetuousness that gradually destroyed a mission that, though conceived in the light of reason, ended consumed by the passion of its component members. All of them were scientists or artists; rational and professional individuals; in the end, however, ordinary men and women who, surrounded by an implacable nature, simply gave way to their impulses.

\section{A PASSION FOR SCIENCE}

In a letter to his teacher, the well-known botanist Andrien de Jussieu, dated on the 18th of December 1833, a naturalist little more than 30 years old, living in Chile for the past four years and on the point of returning there after sailing to France to purchase instruments, confided a remarkable item of information. The message from Claude Gay begins as follows: "When I went to bid you farewell I did not think that within about a month, more or less, I would give you news that is sure to surprise you greatly, that is, my marriage". Thus, in 1834, with the illusion of "a happy union" on the part of the bridegroom, a Calvary began that would come to an end only 11 years later. What had driven the scientist to take a step that, as he himself acknowledged, "in my condition, it would not much benefit me to take". 31 The answer was: a passion. A passion that, by inspiring decisions that turned out to be regrettable for his personal life, kept him on tenterhooks for years, disturbing his work and his activities as a scientist.
According to his major biographers, the arrival in Chile of Claude Gay in early December 1828 was the result of his being hired as professor of the Colegio de Santiago, where classes were to begin in March 1829. The naturalist, who was to become famous thanks to his research and publications on Chile, had been born in March 1800 in Draguignan, department of Var, in Provence, to a family of small agricultural landowners (Stuardo Ortiz, 1973).

It is on record that from early childhood he showed an inclination for the study of Natural Science, in addition to excursions from time to time around his native town. He evokes that time in his diary: "as soon as I felt capable of crossing the severe limits of the mountains, of the Alps, Dauphiné, Savoy, and part of Switzerland. In those places I made a collection of plants that grew considerably with those that other botanists gave me" (Gay, 2008: 88).

About 1820 he arrived in Paris for higher studies in Medicine and Pharmacy. Then he began to attend the public courses in Natural Science at the Museum of Natural History and the Sorbonne. ${ }^{32}$ At that time he took advantage of his holidays to undertake botanizing expeditions outside France or perform commissions for the Museum. During his time in Paris, from 1821 to 1828 , in addition to Botany and Entomology, his favourite subjects, he taught himself Physics and Chemistry, followed some time later by courses in Geology and Comparative Anatomy. In this way he acquired vast knowledge and also began scientific research beside eminent teachers from the Gardens of the King and the School of Mines. His memories of his time with the Botanical Gardens and the Museum of Natural History in Paris are eloquent regarding his vocation: "The abundant collections of objects of natural science, the high scientific level of the courses taught there, the interest of the professors in helping me with my studies, all this contributed powerfully to make me love a science that I had already taken up on my own and studied with my own effort"' (Gay, 2008: 89).

In the diary he began upon starting out on his voyage to Chile, he mentions failed efforts to reach America until he was told that "a society of persons was being organized in Paris with the intention of founding a university in Santiago de Chile under the special protection of the French and the Chilean governments"; then, he declared that "the pleasure joined to the interest of discovering a country unknown to naturalists, led me without hesitation to accept the proposal they made me of appointing me professor of Chemistry and Physics" (Gay, 2008: 91).

Years later, at the beginning of his monumental Physical and Political History of Chile, he stated that his teachers in Paris had suggested the Republic of Chile as the most appropriate to meet the demands of a vast curiosity that compelled him to investigate the productions of some distant clime that did not appear to be much travelled. He took this advice and began to 
take notes of the little that had been said of the history and geography of this part of America.

Accordingly, personal motivations were the main reason that brought Claude Gay to Chile, all arising from his education and experiences that trained him as a qualified naturalist. Indeed -as he wrote- in his contract as professor of Physics, Chemistry, and Natural History of Chile, Claude Gay saw, beyond the start of a career devoted to teaching, the certain possibility of taking up research in a land almost totally unknown to European scientists. In his own words, "since I took up the study of the natural sciences, which are truly sublime, I was seized by the desire to travel, which appears to form part of them" (Gay, 2008: 88).

Passion, love, pleasure, interest, desires, all terms employed by Gay in his writings to explain his visit to Chile, show us a man totally dedicated to knowledge, captivated by scientific activity. Resolved to devote his life, as actually happened, to science.

In fact, as soon as he arrived in Chile he began to visit various sites and to collect specimens, so that in a short time he had formed collections of plants, animals, and rocks. His expeditions delighted him more than his classes. And on the 9th of December 1829 he wrote to Alexandre Brongniart explaining his reasons for coming to Chile and saying that he had "only one day a week available for the benefit of science". He added that, particularly at the beginning of his stay, he had been able to visit "only the environs of Santiago or make a quick trip to the seaside or the mountains". However, he had already completed "a good number of observations that will serve to reveal these lands that are so seldom visited" (Feliú Cruz and Stuardo Ortiz, 1962: 2).

The zeal and passion that Gay showed for natural history, manifest in his indefatigable activity and devotion to study, not only drew the attention of the few individuals interested in the Natural Sciences living in Santiago. They also reached the ears of the authorities, who had been considering the idea of making a scientific study of the country, a long-held aspiration, which it had not been possible to materialize for lack of a competent individual to undertake it.

Given his reputation, it comes as no surprise that the government signed a contract with Claude Gay in September 1830 whereby the scientist was to travel over the territory in order to investigate the natural history of Chile, its geography, geology, statistics, and everything that might reveal the natural products of the country, its industry, trade, and administration.

Having completed the administrative proceedings and necessary preparations for the scientific excursion, Gay was ready to undertake the exploration of the Chilean territory. He began by the province of Colchagua in December 1830 and after a decade of explorations wound up in Atacama in 1841. He had accomplished his desire "not to leave a single corner of Chile without having truly visited it", as he confided to Ignacio Domeyko in a letter dated on the 8th of December 1841.

Owing to his enthusiasm for knowledge, in the course of his excursions and thanks to having made a detailed visit to every province that composed the republic at that time, the naturalist collected most of the animal and vegetable species existing on territory that was recognized as Chilean at the time. Calling attention to this side of his activities, he explained that the only way to acquire knowledge of the various forms of life in each province was to remain "for more or less time in each province, carefully studying from a comparative and above all geographic, point of view, as many objects as one has obtained through research and hunting; only thus is it possible to know the fauna of a country" (Gay, 2010: 5-6). Moreover, everywhere Gay talked to the people and observed their ways of life and working methods, a practice that not only proved highly useful in preparing his book on the history and agriculture of Chile, but particularly in collecting information on historical facts and identifying the special characteristics of the Chilean people. ${ }^{33}$

During sedentary periods, he proceeded to order, classify, describe, draw, and prepare the samples and objects collected, write scientific reports for the Chilean government, and keep up his correspondence with his European colleagues, whom he informed in detail of his studies and the novelties he was discovering as he travelled across the country. In fact, an existence almost entirely devoted to science. An example of the foregoing and of the enthusiasm that nature aroused in him is a paragraph from one of his texts. Referring to nature on the islands of the then existing Lake Tagua-Tagua, he writes that there was such an infinity of "new species, for me as well as for science, that they make of this country a mansion of delight and admiration, where nature has done everything and only awaits the hand of man to rival in beauty and charm the attractive surroundings of Como, Constance, and even Geneva" (from Gay's Viaje científico. Informe a la Comisión Científica sobre sus exploraciones de la provincia de Colchagua, cited by Stuardo Ortiz (1973: 94).

It was an eminently solitary task, except for occasional assistants or companions, or meetings with inhabitants of the areas visited. While travelling across Chile, Claude Gay had to face all manner of adversities and suffer the rigors of extreme weather conditions in some of the areas. According to testimonies of those who knew him, as Barros Arana tells, "he was indefatigable for work, spent entire days on horseback never showing the slightest fatigue, climbed up the highest hills or down the deepest precipices, on foot or on horseback, never hesitating before any peril, withstood hunger and thirst, cold or heat without ever complaining and always with invincible good humour, who slept equally in the open or indoors, and whose robust health never suffered either the consequences of poor food or the results of 
the agitations and inconveniences of those demanding explorations" (Barros Arana, 1911: 284).

For all of the above, it came as a surprise when the scientist, having sailed to Europe to obtain materials for his work, at which time the French government awarded him the cross of the Légion d'Honneur, should return to Chile having married Hermance Sougnier.

It is well known that Gay was reserved, essentially concentrating on his own affairs, though of a fiery nature and active temperament, even vehement when it was a question of science. Described as naïve, amiable, and jovial, he was appreciated as a cultivated spirit, a tireless worker, and a studious man. He was said in practice only to "cultivate relationships with men more or less directly interested in scientific studies" (Barros Arana, 1911: 276). His preference for order and stability is also known, a man removed from radical, even liberal, movements.

For this reason, perhaps, his marriage made an impression on Chilean society, aware of the absolute devotion to study of the husband. And this, perhaps, inspired the words of the irreverent and all-powerful minister Diego Portales, known for remaining stubbornly single and leading a relaxed private life. In a letter to his confidant Antonio Garfias he instructed the latter to tell "Mr Gay that I do not forget his request, and that when he is bored with the little Frenchwoman to send her over here", 34

Little is known of the married life of the Gays in Chile after 1834. We know, however, that from that year until 1842 Gay travelled about the country practically every summer and stayed for months, over a year, for example, in the rainy southern provinces such as Valdivia. He lived with his wife in Valdivia for some time, leaving her alone when he went on his excursions in the interior of the province. $\mathrm{He}$ also lived with her in Coquimbo, the northern province with a semi-desert climate.

Even without information we may presume the reason why Claude Gay married, what drove him to take a step of such importance when he was aware of the task awaiting him in Chile. In the letter to Adrien de Jussieu, quoted above and sent shortly before the marriage, though he admits that "nothing was further from my thoughts than the idea of taking those natural vows", he offers an explanation because, after meditating on his future, he ended by making up his mind upon considering that "this marriage was to my advantage in every way". Thus Gay found himself unexpectedly married shortly before returning to his solitary activities as "travelling botanist" far away from his family and principal relations, supposedly from "estimation", affection perhaps, love maybe, but for science. This is evident, we conclude, in the arguments he gives his teacher in the precious letter we have to examine how this scientist viewed his marriage.
With Jussieu, the fiancé feels "bound to make him the first to know" of his engagement, which does not prevent him from saying that it is also a "pleasure". Then come the explanations and justifications for a decision that, undoubtedly, from the words of the hopeful naturalist, might cause consternation and reproach. "This happy union, my dear friend", he writes, seeking complicity and understanding, "far from hindering my work can only favor it. In fact", he continues, describing the qualities of his fiancée, "this person of the tenderest nature and complete education, at all times, is very fond of painting, which would help her to paint for me the objects of Natural History and as a result I might save some time that I might employ much more usefully. Furthermore, she will be able to help me in many other tasks that her capability and love of instruction may enable her to carry out".

The qualities of the future Mme Gay also include, according to the scientist, total unconcern over "the hardships of the voyage" they must undertake, which, "far from alarming her", we read, shows her "even more delighted because, having visited the main cities of Europe, she has acquired in the course of these journeys a spirit of observation and, therefore, a special taste for travel". Furthermore, continues this veritable list of the merits of a naturalist's assistant, since "our arrival at Bordeaux", whence he writes, the future Mme Gay "wishes only for mountains, mines, volcanoes (she has already climbed the Vesuvius) and above all the beautiful places in the New World that, she says, she expects to visit as a true artist".

In conclusion, after arguing as though presenting a specialized paper, stating the problem, the background, and the hypothesis to be demonstrated, Gay writes to Jussieu hoping for approval from the teacher: "Finally, my dear sir, everything leads me to believe that in this person I shall have not only a good wife, a true friend, but even someone who will be of the greatest use to me".

Would it be straying too far to suppose that Claude Gay, described by everyone as moderate, unassuming, ingenuous, humble, and absolutely committed to knowledge, married not so much for love as because he believed that he had found a comrade in his enthusiasm, a more than occasional assistant in his work, someone with whom to share his passion, but his passion for science? Perhaps not, if we consider that he himself, in the revealing correspondence that provides our evidence, says that having meditated and conscientiously considered the issue, "this marriage for estimation rather than interest was to my advantage from every point of view". The reason: "the great qualities" that, as we have seen, he has noticed in Hermance Sougniez. In short, those qualities were, as he confesses, what "decided a marriage that my position, or rather my attitude, had convinced me that I should always have to oppose". 


\section{MORAL TORMENT}

A private man, Claude Gay confided to very few people the events of his personal life. One of them was Manuel Montt, whom he kept abreast of extremely serious events. ${ }^{35}$ In him also he sought comfort and understanding in the face of losses such as only a friend may be in a position to hear, understand, and, on occasion, alleviate. Thanks to this correspondence we may unveil certain aspects of his unhappy marriage, but also of his near absolute dedication to work (figure 4).

There we learn that from the start he felt "chained within a family full of audacities and intrigues". A marriage that, ten years later, he avers, "made me sign my weakness", and where he had ended up married to a woman "whom from a kind of charity I had drawn out of penury to give her a position to which she could never belong". The scientist thus became the support of "a clan tormented by crazy expenses and

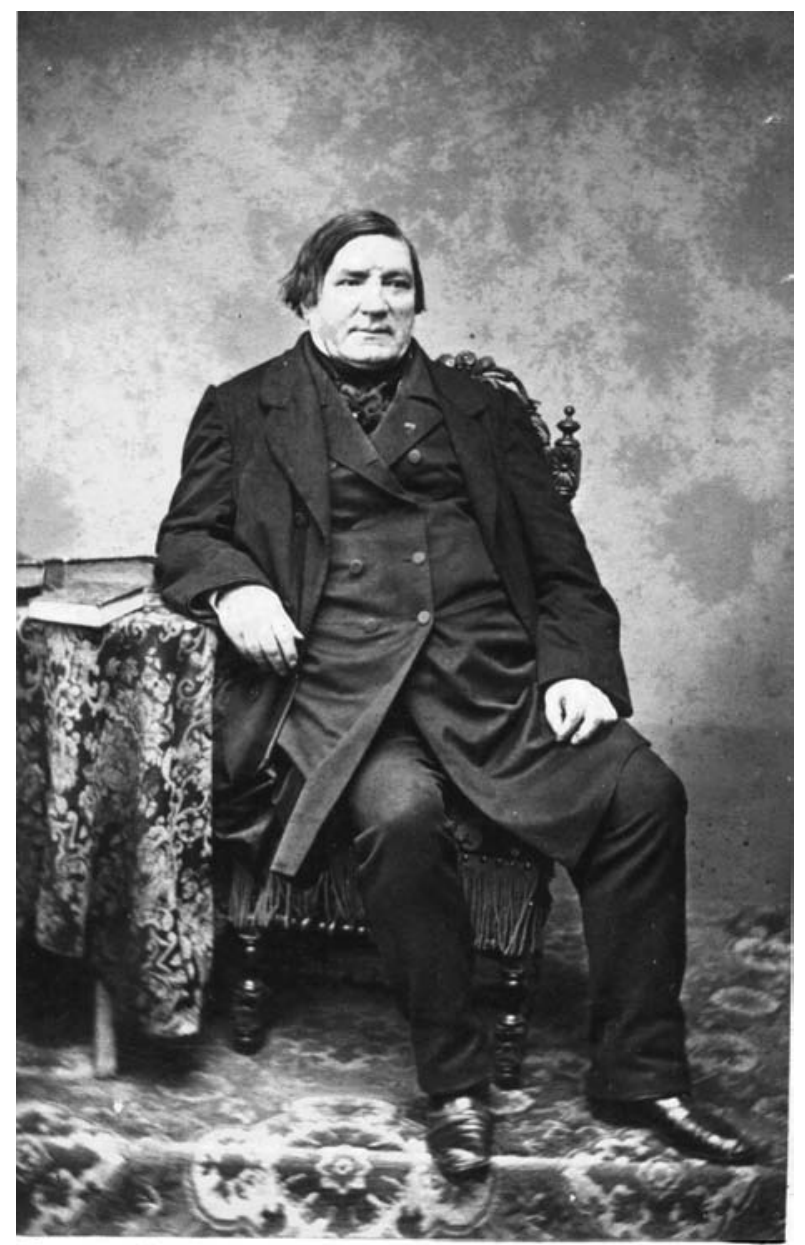

Francesch! Phot.

FIGURE 4. Studio portrait of Claude Gay. The wise scientist, free now from the matrimonial troubles that once tormented him and undoubtedly affected his writings on Chile. Biblioteca Nacional de Chile. overwhelmed by debts and penuries"; compelled to remit from time to time, at the request of Mme Gay, large sums of money, "to the point", the naturalist states, "that I was driven to take measures for those remittances to become as rare as they were difficult". 36 Gay's attitude became for him the cause of "my domestic displeasures" including what he termed the "slander of my wife at the few homes she visited" where she averred that he "tormented her in domestic life" and with fake tears, as the scientist affirms, "knew how to give a certain appearance of truth to her secret and unjust accusations".

We know that Mme Gay was never satisfied with the work of her husband, even less with the circumstances he afforded her. She complained not only that he never took her out to public promenades, that they paid no calls or that her house lacked the proper furniture, but also about his scientific excursions to the interior of the country. Worse yet, according to Claude Gay, she failed to observe proper behaviour in each of the places where they lived. That is why he writes that "already in Valdivia and Coquimbo her levity had given rise to acrimonious criticism".; that he had been obliged to remonstrate with her with no effect, and even to tell her that he would make her return to France, which she roundly refused to do. Recalling their stay in Santiago, he says that although he had been told of the life that his wife was leading, as he could not believe such perfidy, he took the warnings lightly and since he could not bear to demand an explanation, he felt bound to keep silence to avoid scandal. There was no alternative but to "keep her in Chile, promising myself a separation later, if her slandering and perfidious nature did not change". 37

Thus, what in France had appeared to be a promising espousal for the solitary naturalist, turned after marriage into a torment, a source of endless vexation and trouble, which, nevertheless, must have contained some pleasant moments, as may be attested by the birth of a daughter, Teresa. But then this may have been only the fruit of compulsory living together, for in different letters to Ignacio Domeyko, whom both had visited during their stay in Coquimbo, Gay refers to his wife pointing out that "she wanted to return to Paris as soon as possible", or that she does not forgive the Polish scientist for "making me travel to Copiapó", 38

Claude Gay hoped that the return to Paris "after a few sacrifices in money in favor of his parents would mean silencing the vicious tongue of his wife and enjoying that domestic happiness, which, he claims, "is the only thing capable of making people happy on this earth of misery", as he wrote to Manuel Montt in October 1844. The fact is, however, that the family's return to France failed to improve the relationship between the spouses. Moreover, it worsened on the voyage. Writing to Ignacio Domeyko on the 26th of January 1843, Gay tells that "the voyage from 
Valparaiso to Bordeaux has not been very happy, especially for me: I have had many troubles".

The reason he claimed was the behaviour of his wife. In letters to his friend Manuel Montt, he explains "As soon as we boarded the Arequipa, she began to employ the same indiscretion and to annoy me with lewdnesses. Given her disposition, all the passengers, men and women, retreated from her and left her alone as if she had the plague. During the entire voyage, which took one hundred days, she had for company no one but the captain, with whom she led a most reprehensible life", he ends, sadly (Feliú Cruz and Stuardo Ortiz, 1962: 50, 70).

For Gay, who had returned to Paris to begin publication of his work on Chile, the marital situation entailed a heavy burden. This was added to the difficulties surrounding a publishing project of the size of the Historia Física y Politica de Chile, and his quarrels with the representative of the Chilean government in Europe

The dead weight of a mistaken marriage, which in Paris led to divorce proceedings, can be felt in Gay's letters. To Ignacio Domeyko he only reports general news: "I had promised Y.E. to devote myself to finishing my maps; unfortunately, my head has not permitted me to do such work". With Manuel Montt he is more explicit; in September 1843 he writes to him that "my domestic affairs are still the same; I cannot yet obtain a separation, while my peace of mind requires it. I could not live with a person whose behaviour has been so indelicate". The sensitive situation, given the conservative character of Chilean society, leads him to beg his friend to "keep silent about these family affairs". At another time he regrets the delays in his work, and explains, "I am very sorry that most powerful reasons have so far prevented me from giving this undertaking all the activity of which I am capable," 39

Among the concerns of the naturalist were the attempts of his wife to discredit him. "I know that, aided by her evil mother, she endeavours to do me all the harm possible. In France they will not succeed", he comforts himself, "but in Chile, where my numerous occupations prevented me from frequenting society, she has managed to make me some enemies, and some might give credence to her lies and evil ways". What his wife writes and posts to Santiago, which he describes as "slander and lies", probably contributed," Gay surmises," to make me lose the esteem of some families", an idea that, he assures his friend Manuel Montt, " tortures and overwhelms me". He unburdens to Montt on the subject because he sees in him not only the guardian of his honour but above all because he assures him, piteously, "I did not want this slander to attack your good friendship and that of the persons I know and esteem". Then he swears "by what is most sacred to me", that all that she has written to Chile is nothing but slander and that I have always respected her, as a man of honour and reason', 40

Gay's concern was not unfounded for, in fact, in Santiago some families belonging to the national élite did pay attention to the claims of his wife. This was an alarming conclusion for the naturalist, as regards his reputation, and most alarming for his scientific undertaking, owing to the financial support that the Chilean subscribers and the national government gave to it, lacking which it would be impossible to keep up the work. The "slander" against him circulated particularly among the Ochagavías, a family of aristocratic inclinations, staunch Catholics, who spread the intrigues against Gay through the government offices to hinder the materialization of his book (Feliú Cruz, 1973: 146). Sometimes they succeeded, particularly when Silvestre Ochagavía was appointed Minister of Worship and Public Instruction, and was placed in a privileged position to cancel the public funds earmarked for that purpose.

The decisions made in Chile were encouraged from Paris by Ambassador Francisco Javier Rosales, who had, according to Gay, good reasons for his animosity. Among them, judging him "a bad husband", doubtless out of "a spirit of vengeance," Gay wrote to his dear friend Manuel Montt in $1844 .^{41}$ For the naturalist, the attitude of the Chilean diplomat in Paris stemmed from "the little attention I paid him, for as I could not withstand that pride and fatuousness that characterize him, I never set foot inside his home, nor he in mine, so that this civil servant" he says, "has contented himself with irresponsibly repeating what Mme. Gay has told him, as though it were not his duty to examine more carefully such a delicate and serious matter". The fears of the worried scientist were that "his assurance might harm my cause in court," but, above all, "to be unable to erase the poor impression that some Chilean families may have formed from his secret slander". ${ }^{42}$ Given the facts, and with the option to "defend myself by describing the family whom I had the misfortune of joining", Claude Gay writes to Manuel Montt rejecting it, for "to do that I would have to enter into highly unpleasant details, and it is too much against my feelings to take that course, therefore I prefer to keep silent, although I am convinced, I assure you, that it will prove completely contrary to me".

What Claude Gay describes as "torments, whose effects I much regret" undoubtedly influenced "the delay that my publication has suffered until now", he writes to Montt. As a result, undoubtedly, he was "grieved to the highest degree". His sole comfort under the circumstances arising from a serious error in his estimation of his wife's qualities, particularly regarding his passion for the study of nature, was the hope of a prompt resolution of the on going divorce suit. Only then, he declares upon ending his lengthy statement of his personal affairs, "free from all this 
moral torment, I shall be able to devote all my time to my work". 43

Eventually, one year later, Gay could write to Manuel Montt, his "dear friend", letting him know that the divorce proceedings "have ended wholly in my favour", for "the complaint of Madame was denied and the separation was awarded against her". Finally, he adds, "the child was given to me and the mother is only allowed to visit her at the boardingschool, in the presence of a teacher to prevent her from repeating the thousand slanders that she never ceased telling her against me" 44

The news is found at the end of a long letter to Montt intended to report on his Physical and Political History of Chile, whose first volumes appeared in 1844. He responds to the criticisms made to the method employed in preparing the history section and also reports on other issues related to Chile. Such attitude shows that, once freed from a disastrous marriage, the lawsuit, and the worries caused by what he called the "monomania" of his wife, he was now fully concentrated on his own affairs and devoted to his true passion, science. The same passion that had led him to marry and so obtain both wife and assistant.

Nevertheless, the complications arising from a "bad marriage" had not ended, for when the news came to Chile that Gay had obtained a divorce, many people decided to abstain from subscribing to the publication of the scientist and, therefore, from supporting it. For these people, most notably Silvestre Ochagavía, Minister of Justice, Worship, and Public Instruction, rather than the scientific importance of the work, the academic merits of its author, or the significance for Chile of the editorial undertaking involved, the major consideration was that the author was a man "outside the Church" -Feliú Cruz and Stuardo Ortiz (1962: xxiii-xxiv) discuss this situation. In turn, an expression of the rigorous application of religious principles by the conservative Chilean society and how severely it judged the conduct of those who failed to abide by them,

The complicated situation of the Historia fisica $y$ politica took the matter to the report for 1853 of the Minister of Justice, Worship, and Public Instruction, where it was stated that the works of the scientist "were taking too long and caused an encumbrance that was burdensome on the exchequer," for which reason the government had asked that printing of such parts of this work not yet published or only just beginning to be published be suspended until further notice" (cited in Stuardo Ortiz, 1973: 461, 662).

Claude Gay is clear on this point when he writes to Manuel Montt on the ministerial decision: "I cannot abstain from telling you that behind his resolution there may be some reminiscence of the hostile spirit that has moved him against me, which I cannot understand except for his haste in accepting with no proof all the lies that Mme Gay does not fail to disseminate against me". In alarm, he tells the President that the words of the Minister carry weight and can harm him because, in addition, "he does not appear to have become more circumspect about me, and he still endeavours to cast upon me the inconveniences of a lawsuit -for divorce- to suspend which I had done everything that it was possible to do, even to disbursing large sums of money, with the sole object of arranging this wretched matter on friendly terms". 45

Fortunately for the naturalist, his extensive and dramatic appeal to Manuel Montt bore fruit: on the 14th of March 1854 Minister Ochagavía retraced his steps and wrote to the representative of Chile in France informing him that "data recently furnished to the government by the author of the Historia, had led H.E. the President somewhat to expand the instructions furnished to you by this ministry concerning that publication". 46 The ministerial resolution confirmed the governmental support of Gay's work and enabled it to continue thanks to the funds to be raised by the decision.

But Gay's peace of mind was broken also by another event. In 1850, disconsolate, he had written to his friend Manuel Montt "weighed under by the deepest grief that a father can experience". Then he goes on to say that, finding himself in Seville, at the Archive of the Indies, looking over documents for his history of Chile, "I received a letter from the teacher at the boarding-school where my poor daughter was being educated, letting me know that this beautiful child, full of strength and health, had just succumbed to a haemorrhage that gave her not five minutes' respite". Alluding to Montt's "father's heart", he trusted that the latter would ."understand all that I have had to suffer", adding in conclusion, "I do not know what I may have done, but it seems to me that I have been much punished by fate. I hope and trust with all my heart that happiness will prove more constant with you. ${ }^{47}$

Weighed down by the misfortune that had fallen upon him, Gay sought comfort in his work, in the activity of a scientist. In this instance, his text on the natural and civil history of Chile, which, he wrote, "keeps me busy for ten hours a day at least". In the end, the task took almost 27 years to finish, for the first volume out of thirty was published in 1844 and the last in 1871. In September 1856, after publishing practically all the volumes, Gay writes to Montt again. Proudly, he comments on his work and his career, recalling that in the midst of "a solitary life, all the scientific honours have come for me, as laureate or as president of scientific societies, and last year the Institute of France", when he was admitted to the botanical section of the distinguished Paris academy in his capacity of travelling botanist. ${ }^{48}$

A perfect résumé of a life devoted to science, full of professional satisfactions, unhappy in personal and marital terms, among other things, owing to the 
precipitate decision to marry that his needs as a travelling botanist led him to make. At which time his passion for his work seems to have made him confuse the supposed qualities of an assistant with those of a wife. A complication that, despite what was reported above, Georg Langsdorff failed to undergo, since it is on record that his wife, Wilhelmine, helped him and did work as a naturalist. ${ }^{49}$ Although, like Gay, the German nobleman never anticipated the consequences of bringing his wife into his life and work as a scientist.

\section{SCIENCE AND SENSIBILITY}

In the cases presented, it was not only the law, the Church, or society that manipulated or pressured the passionate and troubled travellers who were the protagonists of our tales, censuring forbidden love or intolerable impulse. On the contrary, usually in solitary places, isolated and uncommunicated, they ended by being the victims, at times the fortunate actors, of their own nature. The same that in their role of individuals, persons, with sexual drives and in need of affection, made them forget their role of scientists. A striking example that although on occasion history overlooks the dimensions of the human being or universal feelings, the latter always find a way to express themselves. The scholar must therefore take them into consideration, even when the fact is not so self-evident, as in the case of scientists on an expedition, for, in the final analysis, we are all familiar with the force of passion and emotion in our own lives. The foregoing, on the other hand, cannot make us forget that impressions, by definition, are fleeting, as shown by a paragraph of a letter sent from Madrid, on the 8th of May 1806, by an anguished and lonely Carlos Montúfar to Alexander von Humboldt: "My dearest friend, What a long silence! How long it is that I have not had the pleasure of seeing your handwriting or hearing about your health, until this letter that Bonpland has finally written, telling me that you are well, for here it was rumoured that you were ill. Now and a thousand other times have I written to you and always with no reply; I do not know how to account for your silence" (letter cited in Moreno Yáñez, 2005: 321-322).

\section{ACKNOWLEDGEMENTS}

This work is part of the results of the project by the Ministry of Economy and Finance HAR2010-21333C03-02, and was written in the context of FONDECYT Project 1095221. I thank María Teresa Escobar for the English translation. This article will appear in Spanish in Gonzalbo, Pilar (editor) (2013) Amor e historia. La expresión de los afectos en el mundo de ayer. El Colegio de México, México DF (in press).

\section{NOTES}

1. The entry ends as follows: "Little by little a monotonous life erases these excellent intentions and makes men return to the vulgar class",

2. It was not the first time that Humboldt engaged in such a compromising friendship. He had begun one in 1794 with Lt. Reinhard von Haften, reaching such extremes of intimacy that he dreamed of settling down with him in America "to live apart from the so-called cultivated people and lead a quiet and happy life". For Hanno Beck, his biographer quoted above, though this friendship had its bounds, including the fact that Humboldt was not requited, the fact is that "it is possible that Humboldt might exceed with his affection the limits of the feelings that nature sets on a friendship between men". Bearing in mind that Beck's work was published in 1959, the full significance may be realized of this association that Beck describes as a "cult of friendship suddenly inflamed". Including subsequent paragraphs designed to show a presumed interest or romance of Humboldt and Henriette Herz (Beck, 1971: 80,81 ).

3. Humboldt, describing to his brother the "horrors and perils" with which nature has surrounded the quiteños, concludes "this is how man gets used to sleeping peacefully on the edge of a precipice". His views on Quito undoubtedly show an animated Humboldt, prepared to tell his brother and closest confidant descriptions, situations, and characterizations habitually absent from his scientific texts.

4. One of those selected to travel was astronomer Jean-Paul Granjean de Fouchy, who excused himself on grounds of ill health, although in fact -as he wrote to Godin- he was in love and seeking marriage. That is why Godin wrote to him from Quito on 9 May 1737: "Truly, you have very pleasurably exchanged a journey to Peru for a condition much to your advantage and travel to another country where the glory of action is reserved for you alone" (Badinter, 2007: 240).

5. Badinter (2007: 83) issues a warning on the use of correspondence as "advertising to support travel", even when it turns out badly, as in the present case.

6. The history of the undertaking is described in Lafuente and Mazuecos (1987). This work contains no mention of our subject matter.

7. Biblioteca del Museo de Historia Natural, Ms. 179, f.5. Cited by Badinter, (2007: 82-83). Unless otherwise noted, all citations on the journey to Ecuador are taken from this source.

8. Biblioteca del Museo de Historia Natural, Ms. 179, f. 15. Cited by Badinter (2007: 83)

9. The main source for these events is the so-called "Autos formados de oficio de la Real Justicia y a instancias de los albaceas del difunto don Jean Séniergue, botánico y cirujano de la Compañía Francesa, muerto en la ciudad de Cuenca a mano violenta. Quito, septiembre 2 de 1739", in Archivo Nacional de Historia, Quito, Sección Criminales, Expediente 5. Condamine (1921), written in 1773, also contains a number of documents dealing with the so-called Cuenca mutiny and death of the French surgeon.

10. Statements of La Condamine before the Real Audiencia of Quito, in "Autos..." (op. cit.) and Letter to señora *** about the popular uprising that took place in Cuenca, Peru, on 29th August, 1739, "where señor Séniergue, surgeon to the king, was killed", in Condamine (1921: 133-158).

11. According to González Suárez (1890-1903), “it is on record that the surgeon of the French Expedition was a proud man of violent nature; in Cuenca he was hated because, taking advantage of the miserable patronage of the Corregidor, he committed several crimes that went unpunished"

12. In Spanish historiography, for example in Lafuente and Mazuecos (1987) and also in Lafuente and Sellés (1988), the reason why Godin remained in America was the impossibility of repaying the debts se had incurred to finance the expedition in his charge. Doubtless a true fact, but not his only reason for staying in Lima.

13. As Badinter (2007: 287) points out, the exclusion was due to Godin's behaviour and misappropriation of funds whereof he was accused and found guilty. 
14. The note from Malaspina is dated in Callao, 17 September, 1790 and is reproduced in full in Sagredo Baeza and González Leiva (2004: 301)

15. The account of this commission can be found in the manuscript by Moraleda Viage al reconocimiento de las Yslas de Chiloé. Año de 1786, Museo Naval, Ms. 613, Madrid.

16. The study of the activities of Moraleda, his voyages on the Pacific and Atlantic, and other travels motivated by his campaigns in Chiloé, Patagonia, and Central America are no only proof that his life was devoted to exploring the South Sea, and that his part in the reconnoitring of America is fundamental. It further shows the application in America of the most modern piloting procedures of his time. Moreover, the reception and use of the new methods for calculating longitude, as well as other knowledge that enabled him not only to steer the ships he piloted but also to conduct explorations, draw charts, and perform geographic surveys that, like those completed in Chiloé and Patagonia, would remain valid for a long time. See Sagredo Baeza (2009).

17. Recommendations of commander Manuel Fernández de Bedoya and of Manuel de Guirior, cited by O'Donnell y Duque de la Estrada (1990: 73-74).

18. Madrid, August 26, 1797. Archivo General de Indias, Seville [AGI], Chile, Leg. 217, cited by O'Donnell y Duque de la Estrada (1990: 100).

19. Lima, 26 May, 1789. [AGI], Chile, Leg. 221, cited by O’Donnell y Duque de la Estrada (1990: 101).

20. Lima, 26 May, 1789. [AGI], Chile, Leg. 221, cited by O’Donnell y Duque de la Estrada (1990: 101).

21. According to O'Donnell y Duque de la Estrada, (1990: 191), Moraleda's "willingness to stay" was due to the "double pay and free board and page services he enjoys during his commission".

22. [AGI] Chile, Leg. 218, cited by O'Donnell y Duque de la Estrada (1990: 193)

23. [AGI] Chile, Leg. 221, cited by O'Donnell y Duque de la Estrada (1990: 80)

24. In Sagredo Baeza (2010a), I report the campaign and the poor opinion that the seaman formed of this southern region.

25. Costa and Diener (1995 and 2013) have rescued from oblivion this ill-fated expedition. In their works, together with their own discussion and interpretation, they present new documents containing not only the day-to-day events, but also the feelings of the members of the expedition, thus helping us to build our own version.

26. Costa and Diener (2013) are right in concluding, in the light of their research, that the association of art and science is a central point for understanding the fate of this enterprise, as the players involved had very different notions of the role played by the artists in the expedition. Rugendas never accepted being subordinated to Langsdorff; let alone giving up representing, rather than registering, the natural reality he admired.

27. Letter from Aimé Adrien Taunay to Francisco Álvares Machado, dated in Cascada del Tamanduá, río Pardo, probably on 26 September, 1826. Document No. 13. in Costa and Diener (2013).

28. Letter of resignation from A. A. Taunay to G. H. von Langsdorff, dated in Cuiabá, probably before 30 September, 1827. Document No 14. in Costa and Diener (2013).

29. Letter from Aimé Adrien Taunay to Francisco Álvares Machado, dated in Cuiabá, 30 September, 1827. Document No 15. in Costa and Diener (2013).

30. Letter from Aimé Adrien Taunay to his relatives, dated in Vila Bela, 30 December 1827. Document No 16 in Costa and Diener (2013)

31. Letter, in Feliú Cruz and Stuardo Ortiz (1962: 7-9).

32. He was to write in his diary: "The study of medicine seemed to me the most seductive and the one most suited to my tastes. Unfortunately, my ever-growing passion for natural history made me abandon it and that is something that I shall regret all my life" (Gay, 2008: 90).

33. In the prologue to Agricultura, the scientist alludes to his "long trips in Chile, when I visited its immense haciendas. . . I thought of making a detailed study... as a simple chapter of a general work on Chile..., but as my investigations increased, my notes grew to such an extent and became so interesting that they acquired the dimensions of a book of great bulk" (Gay, 2010).

34. See letter dated in Valparaiso on 20th June, 1834, in Portales (2007: II, 46). Portales was the strong man in Chile between 1830 and 1837.

35. Manuel Montt was not only a distinguished politician. His qualities made him President of the Republic and he served from 1851 to 1861 , after having been several times minister, and for many years, deputy and senator. When his Presidential term ended, he became President of the Supreme Court. While he was a minister and all the more while he was President, he gave full and decisive support to the work of Claude Gay. Among other reasons, because he trusted the qualities of the scientist, but also because he thought of his work as a necessary undertaking of the Chilean State. See Sagredo Baeza (2010b: 165-233).

36. Letter dated in Paris, 25 October 1844. In Feliú Cruz and Stuardo Ortiz (1962: 69-72).

37. All in the letter of 25 October 1844. In Feliú Cruz and Stuardo Ortiz (1962: 70, 71)

38. Notes dated in Santiago, 9 August and 11 September 1841. In Feliú Cruz and Stuardo Ortiz (1962: 30, 34).

39. Letters dated in Bordeaux, October, 1842 and in Paris, 12 September 1844. In Feliú Cruz and Stuardo Ortiz (1962: 44, 68)

40. See letters dated in Paris, 12 September 1843 and 25 October 1844. In Feliú Cruz and Stuardo Ortiz (1962: 62, 70).

41. In confidence, Gay writes of what he thinks are also reasons for the animosity of the Chilean representative: "Since we are on the subject of señor Rosales", he writes to Montt, "I cannot but tell you how vexed I have been. Always ready to criticize everything, he cannot understand that the government and the most distinguished families in Chile have to give some signs of estimation to such a humble individual, incapable of properly tying a cravat; therefore, with that air of superiority and that tone of grandeur that characterizes him, he looks at me almost as though I were a workman, trying to belittle me. See the letter dated in Paris, 7 September 1843, in Feliú Cruz and Stuardo Ortiz (1962: 79).

42. See letter quoted above, dated in Paris, 25 October 1844, in Feliú Cruz and Stuardo Ortiz (1962: 71).

43. See letter dated in Paris, 25 October 1844, in Feliú Cruz and Stuardo Ortiz (1962: 71).

44. Note dated in Paris, 7 September 1845, in Feliú Cruz and Stuardo Ortiz (1962: 82-83). Years later Gay used the custody of the child, which was awarded to him in court, as proof of correctness. In November, 1853, vis-à-vis accusations coming from Chile, he wrote: "The results in my favor should make him understand that no judges will take a child away from its mother without good and serious reason".

45. See message of 14 November 1853, in Feliú Cruz and Stuardo Ortiz (1962: 121-125).

46. Text with instructions of Ochagavía. Archivo Nacional. Ministerio de Justicia e Instrucción Pública. Copiador de oficios y decretos. 1854. Reproduced in Stuardo Ortiz (1973: 465).

47. See letter dated in Paris, 15 August 1850, in Feliú Cruz and Stuardo Ortiz (1962: 116).

48. See letter dated in Paris, 15 September 1856, in Feliú Cruz and Stuardo Ortiz (1962: 131, 132).

49. Stated by Costa and Diener (2013). There the authors maintain that there are records of times when the girl makes the notes in her husband's diary and that the collection of pictures of the expedition includes botanical drawings made by her hand.

\section{REFERENCES}

Badinter, Elisabeth (2007) Las pasiones intelectuales. Deseos de gloria (1735-1751). Translated by Falcón, Alejandrina. Fondo de Cultura Económica, Argentina.

Barros Arana, Diego (1911) "Don Claudio Gay: su vida y su obra". In Obras completas de Diego Barros Arana. Imprenta Cervantes, Santiago, vol. XI, pp. 239-457. 
Beck, Hanno (1971) Alexander von Humboldt. Fondo de Cultura Económica, México.

Caldas, Francisco José (1978) Cartas de Caldas Academia Colombiana de Ciencias Exactas, Físicas y Naturales, Bogotá.

Condamine, C. de la (1921) Relación abreviada de un viaje hecho por el interior de la América meridional. Calpe, Madrid.

Costa, Maria de Fátima and Diener, Pablo (1995) Viajando nos Bastidores. Documentos de Viagem da Expediçao Langsdorff. UFMT, Cuiabá.

Costa, Maria de Fátima and Diener, Pablo (2013) Bastidores da Expediçao Langsdorff (in press).

Feliú Cruz, Guillermo (1973) "Claudio Gay, historiador de Chile. Ensayo crítico". In Vida de Claudio Gay. Escritos y documentos, edited by Stuardo Ortiz, Carlos. Nascimento, Santiago, pp. 139-223.

Feliú Cruz, Guillermo and Stuardo Ortiz, Carlos (1962) "Claudio Gay a través de su correspondencia". In Correspondencia de Claudio Gay, edited by Feliú Cruz, Guillermo and Stuardo Ortiz, Carlos. Ediciones de la Biblioteca Nacional, Santiago, pp. VII-LXXXVI.

Gay, Claudio (2008) Diario de su primer viaje a Chile en 1828. Ediciones Fundación Claudio Gay, Santiago.

Gay, Claudio (2010) Historia física y política de Chile. Cámara Chilena de la Construcción, Pontificia Universidad Católica de Chile and Biblioteca Nacional, Santiago. See also http://www. bibliotecafundamentos.cl/images/documentos/gay/gay-historia1.pdf [accessed 20/November/2012].

González Suárez, Federico (1890-1903) Historia general de la república del Ecuador, 7 vols. Imprenta del Clero, Quito. http://goo.gl/j0pUC [accessed 01/December/2012]

Hernández Asencio, Raúl (2008) El matemático impaciente. La Condamine, las pirámides de Quito y la ciencia ilustrada $(1740-1751)$. IEP, IFEA and Universidad Andina Simón Bolívar, Lima.

Humboldt, Alexander von (1989), Cartas americanas. Compilation, prologue, notes and chronology by Minguet, Charles. Biblioteca Ayacucho, Caracas.

Humboldt, Alexander von (2003) Cuadros de la naturaleza. Los Libros de la Catarata, Madrid.

Humboldt, Alexander von (2005) Alexander von Humboldt. Diarios de viaje en la Audiencia de Quito, edited by Moreno Yáñez, Segundo E. Translated by Borchardt de Moreno, Christiana. OXY, Quito.
Lafuente, Antonio and Mazuecos, Antonio (1987) Los caballeros del punto fijo. Ciencia, politica y aventura en la expedición geodésica hispanofrancesa al virreinato del Perú en el siglo XVIII. Serbal/CSIC, Madrid.

Lafuente, Antonio and Sellés, Manuel (1988) El Observatorio de Cádiz (1753-1831). Ministerio de Defensa, Madrid.

Moreno Yáñez, Segundo E. (2005) “Itinerario de Humboldt en la Audiencia de Quito". In Alexander von Humboldt. Diarios de viaje en la Audiencia de Quito, edited by Moreno Yáñez, Segundo E. and translated by Borchardt de Moreno, Christiana. OXY, Quito, pp. 34-35.

Núñez, Estuardo and Petersen, Georg (2002) Alexander von Humboldt en el Perú. Diario de viaje y otros escritos. Banco Central de Reserva del Perú, Lima.

O’Donnell y Duque de la Estrada, Hugo (1990) El viaje a Chiloé de José Moraleda (1787-1790). Editorial Naval, Madrid.

Sagredo Baeza, Rafael (2009) "Navegación científica en el Mar del Sur. El piloto Moraleda (1772-1810)". Revista Digital de Historia Iberoamericana, 2/1: 46-79. http://revistahistoria. universia.cl/pdfs revistas/articulo 89 1250114582587.pdf [accessed 20/November/2012]

Sagredo Baeza, Rafael (2010a) "Navegando entre ríos de nieve. El piloto Moraleda en la costa patagónica". NDHIR Revista Electrónica Documento Monumento. Edición Especial Ríos e Historia: 51-72. http://200.17.60.4/ndihr/revista-3/artigos/rafael-sagredo.pdf [accessed 20/November/2012].

Sagredo Baeza, Rafael (2010b) "Ciencia, historia y arte como política. El Estado y la Historia física y politica de Chile de Claudio Gay". In Ciencia-Mundo. Orden republicano, arte y nación en América, edited by Sagredo Baeza, Rafael. Centro de Investigaciones Diego Barros Arana and Editorial Universitaria, Santiago, pp. 165-233.

Sagredo Baeza, Rafael and González Leiva, José Ignacio (2004) La Expedición Malaspina en la frontera austral del imperio español. Editorial Universitaria and Dirección de Bibliotecas, Archivos y Museos, Santiago.

Stuardo Ortiz, Carlos (1973) Vida de Claudio Gay. Escritos y documentos. Editorial Nascimento, Santiago.

Portales, Diego (2007) Epistolario. Ediciones Universidad Diego Portales, Santiago.

Vásquez de Acuña García del Postigo, Isidoro (2004) Historia naval del reino de Chile. 1520-1826. Compañía Sudamericana de Vapores S.A., Santiago. 